\title{
Det nationale register 1921
}

- tilblivelse og indhold

\author{
af Hans H. Worsøe
}

Efter Genforeningen i 1920 blev befolkningen i Sønderjylland (Nordslesvig) registreret i »det nationale register«. Denne registrering var nødvendig for at man kunne konstatere, hvem der var berettiget til at få dansk indfødsret. Det nationale register er en meget vigtig historisk kilde, som nu findes $\mathrm{i}$ Landsarkivet i Aabenraa. Landsarkivar Hans $\mathrm{H}$. Worsøe fortæller her om registrets tilblivelse og om nogle af de mange forskningsmuligheder, som materialet rummer.

\section{Baggrunden}

Efter at Den Internationale Kommision ved bekendtgørelse af 15 .juni 1920 havde meddelt, at dens myndighed ophørte fra og med 16.juni 1920 og Danmark havde overtaget suveræniteten over de sønderjyske landsdele, der havde stemt sig tilbage, begyndte de danske love, der gradvis skulle indføre den danske administration og lovgivning, $i$ en bred strøm at blive udsendt af de pågældende ministerier. I den forløbne tid siden slutningen af november $1918 \mathrm{var}$ der gjort et grundigt forberedende arbejde i Vælgerforeningens udvalg, i de nedsatte rigsdagsudvalg, i Det midlertidige Ministerium for sønderjyske Anliggender og ikke mindst $\mathrm{i}$ det såkaldte Kriegerudvalg, hvis drivende kraft var Martin Hammerich. Allerede i sidste halvdel af juni 1920 udsendtes 92 love, bekendtgørelser og anordninger. Andre bestemmelser var endnu ikke modne til udsendelse, således er Lov nr. 74 om Erhvervelse af dansk Indfødsret i Anledning af de sønderjyske Landsdeles Indlemmelse i Danmark først dateret 5. sept. 1920. Ialt udsendtes i 1920180 love, anordninger og bekendtgørelser vedr. Sønderjylland, inden året d. 31. december afsluttedes med Bekendtgørelse om en mellem Danmark, det britiske Rige, Frankrig, Italien og Japan den 5. Juli 1920 afsluttet Traktat vedrørende Slesvig, hvorved suveræniteten over de sønderjyske landsdele fra 15. juni 1920 under henvisning til Versaillestraktatens ordlyd blev overdraget til Danmark. I traktaten fastsættes og beskrives forlobet af den nye grænse, og dens indhold er forudsætningen for, at indbyggerne i de sønderjyske landsdele kunne få dansk indfødsret og dermed blive danske statsborgere.

Hermed var lovgivningsarbejdet imidlertid langt fra at være afsluttet, og der forestod desuden det store arbejde med at få den nye danske lovgivning indarbejdet og på længere sigt at afskaffe de sønderjyske særbestemmelser. 
Som bekendt er dette arbejde endnu ikke afsluttet. Man behøver blot at tænke på særbestemmelserne om civilstandsregistrering, hvor det var meningen, at de danske bestemmelser skulle omformes med de sønderjyske (prøjsiske) som forbillede, men hvor man stadig kører med forskellige bestemmelser og i Sønderjylland til en vis grad med dobbeltregistrering. Disse aspekter vil blive taget op til behandling $i$ en senere artikel $i$ forbindelse med genforeningsjubilæet $i$ 1995.

\section{Loven om dansk indfodsret}

Som nævnt ovenfor udsendtes den 5. sept. 1920 en lov om erhvervelse af dansk indfødsret $\mathrm{i}$ de indlemmede landsdele. Det fastslåes her i paragraf 1, at dansk indfødsret har de personer, som den 15. juni 1920 havde fast bopæl i de sønderjyske landsdele og indtil dette tidspunkt var $\mathrm{i}$ besiddelse af tysk statsborgerret, medmindre de havde bosat sig i landsdelene efter 1.oktober 1918. I paragraf 2 åbnes der mulighed for, at personer, der har dansk indfødsret efter paragraf 1, kan optere for Tyskland inden 15. juni 1922, og endelig åbnes der i paragraf 3 mulighed for, at personer, som er født i de sønderjyske landsdele, men ikke har dansk indfødsret i medfør af paragraf 1, ligeledes inden 15.juni 1922 kan optere for Danmark og opnå dansk indfødsret. De følgende paragraffer omhandler efter hvilke regler indfødsretten også omfatter nære familiemedlemmer, herunder at uægte børns statsborgerlige stilling retter sig efter moderens. I paragraf 6 bestemmes, at bevis for dansk indfødsret erhvervet ved option udstedes af indenrigsministeren, og endelig fastslår paragraf 7, at bestemmelserne i paragraf 1 ikke gælder for prøjsiske statstjenestemænd og familie, hvis de forlader Danmark inden 15. september 1920.

Ud over de ovenfor citerede bestemmelser om personkredsen, der blev berørt af loven, indeholder paragraf 1 desuden følgende administrative forskrifter:

Indenrigsministeren bemyndiges til at foranledige, at der optages registre over de personer, der opfylder de i denne paragrafs 1ste stykke fastsatte betingelser.

Bevis for, at en person har dansk indfødsret i medfør af denne paragrafs 1ste stykke, meddeles af indenrigsministeren eller efter nærmere af indenrigsministeren givne forskrifter af vedkommende amtmand.

Ved lovens forelæggelse i Folketinget d. 28. august 1920 anførte indenrigsminister Sigurd Berg, at bemyndigelsen til at optage registre over de personer, der opfyldte kravene i stykke 1, var indsat efter meget indtrængende anmodning fra sønderjysk side, idet man meget rigtigt gjorde galdende, at medens det ikke ville være vanskeligt nu at præstere bevislighederne med hensyn til bopælsbetingelserne, kunne det senere være meget vanskeligt at skaffe disse, 
hvorfor det ville være heldigt at have registrene at holde sig til. Planerne om, hvorledes registrene skulle udarbejdes synes også allerede på dette tidspunkt at være gennemtænkt, men man undervurderede tilsyneladende vanskelighederne ved at fremskaffe de omtalte bevisligheder. Lovforslaget gik uden besvær gennem de tre behandlinger i Folketinget og Landstinget.

\section{Indenrigsministeriets bestemmelser}

Med disse bestemmelser var betingelserne skabt for oprettelse af de nationale registre og for amtmandens centrale placering i denne sammenhæng. Når der skulle gå endnu godt et halvt år, inden man kunne iværksætte udarbejdelsen, skyldes det, at man simpelthen ikke rådede over tilstrækkeligt nøjagtige opgørelser over landsdelens indbyggere til at kunne udfærdige listerne. Disse blev først tilvejebragt ved den folketælling, som blev gennemført i hele Danmark 1. februar 1921, og det blev således optællingen af indbyggerne på dette tidspunkt, og ikke på genforeningsdagen, der kom til at danne grundlaget for de nationale registre. Skemaerne for de sønderjyske landsdele fik en særlig udformning, idet der her indføjedes en rubrik med oplysning om bopæl den 1.oktober 1918, da denne oplysning var vigtig for opnåelsen af dansk indfødsret. Da folketællingen var afsluttet, og resultaterne indkommet til Det statistiske Departement, kunne indenrigsministeren omsider den 25. april 1921 underskrive "Cirkulære til Amtmændene over Haderslev, Aabenraa, Sønderborg og Tønder Amter« om oprettelse af nationale registre, og hele det store apparat kunne gå igang. Det kunne være fristende samtidig at gå nærmere ind på hele spørgsmålet om meddelelse af dansk indfødsret, men da dette i høj grad vil komplicere fremstillingen, vil kun de aspekter blive medtaget, som har direkte betydning for udformningen af de nationale registre.

Forste del af arbejdet bestod $i$, at de indkomne folketællingsskemaer blev bearbejdet på Statistisk Departement. Af skemaerne, som hver omfattede en ejendom, fremgik det, hvor enhver person havde haft natteleje natten mellem 31. januar og 1. febr. 1921, samt - og det var som nævnt specielt for de sønderjyske skemaer - hvor vedkommende havde haft fast bopæl 1.oktober 1918. De øvrige oplysninger har ikke relevans i denne sammenhæng, bortset fra, at der for hver ejendom desuden var et tillægsskema for midlertidigt fraværende, ligeledes for de sønderjyskes vedkommende med oplysning om fast bopæl 1. oktober 1918. En stor del af disse mange oplysninger blev nu udskrevet på nye skemaer, der hvert omfattede en husstand d.v.s. husfader, samlevende hustru og børn under 18 år, eller enkeltpersoner som f.eks. enker, tjenestefolk m.v. På disse skemaer, som kom til at udgøre det egentlige grundmateriale $\mathbf{i}$ de nationale registre, anførtes i første omgang amt, sogn, kommune og adresse samt hovedpersonens efternavn, samtlige fornavne, fødselsdag og -år, ægteska- 


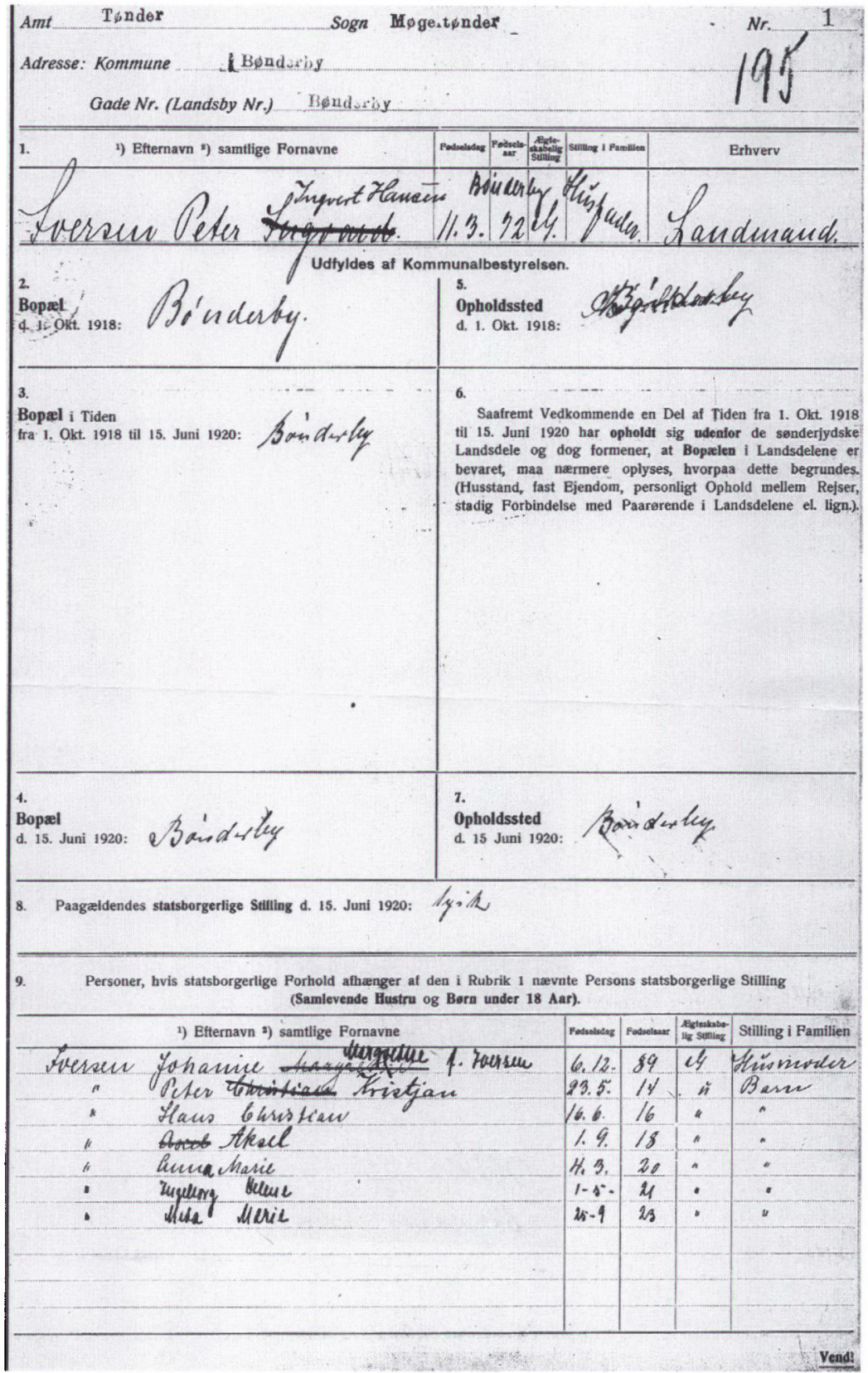

Skema fra det nationale register familien Iversen i Bonderby. (Landsarkivet: Nationalt Register. Tonder Amt. Nr 410). 
belig og familiær stilling samt erhverv+tilsvarende oplysninger om samlevende hustru og børn under 18 år. Skemaerne var desuden forsynet med et løbenummer. Dette arbejde blev afsluttet i løbet af forsommeren 1921, hvorefter skemaerne blev tilsendt de 4 amter sorteret ud på sogn og kommune. Skemaerne betegnes herefter registerblade. Som eksempel på, hvordan det videre arbejde forløb, er valgt Aabenraa amt, hvor amtmand Kresten Refslund Thomsen residerede.

Allerede før udstedelsen af loven om erhvervelse af dansk indfødsret var der mulighed for, at man ved en ansøgning gennem amtet kunne få udstedt indfødsretsbevis fra Indenrigsministeriet. Med lovens fremkomst blev denne mulighed mere almen kendt og benyttet. Af Aabenraa amts journal fremgår det, at Indenrigsministeriet indtil begyndelsen af sept. 1920 havde fremsendt 27 andragender om dansk indfødsret til udtalelse ved amtet. I den følgende tid indkom ansøgningerne til amtet og ekspederedes derfra videre, men i nogle tilfælde kunne amtet selv resolvere i henhold til lovens paragraf 1 . I den resterende del af året behandledes yderligere 150 ansøgninger ved amtet, og i den følgende tid indtil det nationale registers oprettelse fortsatte strømmen. For at bevare oversigten over de udstedte indfødsretsbeviser anlagde amtet en særlig kronologisk ført protokol. For tiden frem til midt $i$ august 1921 omfatter den ialt 2500 personer. Blandt de første fra Aabenraa amt er kaptajnerne Georg Schlaikier og Jacob Petersen (Ensted), dr.med. Harald Nielsen, Aabenraa, og skibsreder Johan Jacob Jebsen med familie.

\section{Materialet gennemgåes på amterne}

Som næste led i det nationale registers udfærdigelse blev samtlige registerblade nu gennemgået på amtet og, forsåvidt der allerede forelå en indfødsretsbevilling, forsynet med et særligt stempel, der henviste til Indenrigsministeriets eller amtets resolution og amtets registernummer, således at man der kunne kontrollere enkeltheder om fornødent. Stemplets tekst afsluttedes med ordene: Optages i Nationalt Register Aabenraa Amt. Herefter blev samtlige registerblade af amtet tilstillet de enkelte kommunalbestyrelser. Dette skete for Aabenraa amts vedkommende fra slutningen af juni til begyndelsen af august 1921, men først 22. august udsendte amtet en udførlig instruks underskrevet af amtmand Kr. Refslund Thomsen. Samtidig fremsendte amtet blanketter til udfærdigelse af bopælsattester og fortryk til fortegnelser over udstedte bopælsattester inden for de enkelte sognekommuner. For Aabenraa bys vedkommende drejede det sig om ialt 3953 skemaer, for Løjt sogn om 1208 (fordelt på de seks gamle kommuner Barsmark med 309, Barsø 33, Bodum 114, Høgebjerg 44, Løjt Kirkeby 554, Skovby 100 og Stollig med 154) for blot at nævne et par eksempler. 


\section{De kommunale udvalg nedsettes}

På dette tidspunkt var den danske kommunalordning endnu ikke trådt i kraft overalt, hvilket komplicerede sagen noget. Da de gamle kommuner imidlertid var betydeligt mindre end de nye sognekommuner, måtte man formode, at de gamle kommunerådsmedlemmer havde det største lokalkendskab. Amtmanden henstillede derfor, at man fortrinsvis valgte de tidligere kommunerådsformænd og kommuneforstandere til de udvalg der nu blev nedsat, et for hver af de tidligere kommuner, sammen med den nye sognerådsformand, hvor en sådan var valgt. Var den danske ordning endnu ikke trådt i kraft, var det lettere, idet kommunerådsformændene og de tidligere kommuneforstandere nærmest var selvskrevne. Endelig kunne personregisterførerne af praktiske grunde tilknyttes disse udvalg, der skulle nedsættes inden 1. sept. og hurtigst muligt træde sammen. Udvalgenes opgave var i første omgang at kontrollere og supplere de oplysninger, som var indeholdt på de fremsendte registerblade, og dette skulle ske på følgende måde:

Alle blade forsynet med amtets stempel henlagdes i en mappe betegnet med bogstav A medmindre amtet i særlige tilfælde havde ønsket supplerende oplysninger f.eks. om børn, men dette kan der her sees bort fra.

De øvrige blade blev derefter omhyggeligt gransket i udvalgene med henblik på at fastslå, hvorvidt pågældende i tiden fra 1. oktober 1918 til 15.juni 1920 havde fast bopæl i kommunen, og om vedkommende indtil 15. juni 1920 var tysk statsborger, og altså dermed opfyldte betingelserne for at blive optaget $\mathrm{i}$ det nationale register. Det blev pålagt udvalgene nøje at undersøge forholdene ved hjælp af forhåndenværende melderegistre og evt. personlig indkaldelse af vedkommende til at møde for udvalget og redegøre for sine forhold og belægge disse med bevisligheder. Omkring punktet »fast bopæl« opstod mange diskussioner, selvom der var taget højde for de fleste tvivlstilfælde ved et særligt cirkulære til amtmændene fra Indenrigsministeriet, dateret 31.marts 1921, bl.a. med hensyn til indkaldte til tysk krigstjeneste, krigsfanger, der først var kommet hjem efter 1. oktober 1918, samt personer, der under krigen var rømmet til Danmark for at undgå tysk krigstjeneste. Disse grupper kunne ligeledes optages som havende fast bopæl, hvis de var født i landsdelene eller havde bevaret en nær tilknytning til dem. Det samme gjaldt søfarende. Derimod skulle personer tilhørende de pågældende grupper nærmere dokumentere deres faste tilknytning, hvis de ikke var født $\mathrm{i}$ landsdelene eller, som det hedder $\mathrm{i}$ cirkulæret: »Kunne siges af være opvokset $\mathrm{i}$ landsdelene og optaget $\mathrm{i}$ disses faste befolkning «.

Skemaerne for personer, der opfyldte ovennæunte betingelser, fik en midlertidig påtegning herom og betegnedes med bogstav $\mathrm{B}$, medens skemaerne for de, som ikke opfyldte betingelserne, betegnedes med bogstav C. Denne første 
sortering afsluttedes i løbet af september måned, så det har virkelig skullet gå stærkt. I sidste uge af september samledes hver kommunes udvalgsmedlemmer med hele kommunalbestyrelsen, hvor samtlige skemaer blev gennemgået. Alle skemaer fra B-gruppen, som blev godkendt, fik en påtegning herom, og optagelsen af de pågældende personer i det nationale register var dermed godkendt.

\section{Kommunalbestyrelserne overtager problemerne}

De personer, hvor kommunalbestyrelsen ikke kunne godkende bevislighederne, overførtes til gruppe C. Tilsvarende kunne det ske, at kommunalbestyrelsen kunne overføre blade fra gruppe $\mathrm{C}$ til $\mathrm{B}$.

Tilbage stod nu behandlingen af "problembørnene«, gruppe $\mathrm{C}$, dem der ikke umiddelbart var blevet optaget. Til dem udsendtes der senest 1. oktober enslydende breve om inden 1. december at skaffe den fornødne dokumentation (som f.eks. fødselsattest, militærpas eller »Staatsangehörigkeitsausweis«) samt bopælsattest for samtlige steder, hvor man havde boet i perioden 1. oktober 1918 til 15. juni 1920. Det var en kort frist, men det blev samtidig pålagt kommunerne, at bopælsattester skulle udfærdiges inden 3 dage efter modtagelsen af anmodningen. Ved de enkelte kommuner blev der samtidig anlagt de tidligere omtalte fortegnelser over udstedte bopælsattester, som er et godt supplement til de bevarede melderegistre.

I første uge af december behandlede de samlede kommunalbestyrelser de indkomne andragender om optagelse enkeltvis. De godkendte blade fik de nye oplysninger påført sammen med tilføjelsen "Attesteres $\mathrm{i}$ henhold til indsendt særligt andragende med bilag om optagelse $\ll$. Disse blade overførtes til gruppe B., hvor samtlige blade nu med blæk fik påtegningen "Optages«. Samtidig udsendtes der breve til de personer, hvis anmodninger var blevet afslået, idet der blev gjort opmærksom på, at kommunens afgørelse kunne forelægges amtet. Den sidste restgruppe - de som ikke havde svaret på kommunens brev fik en påtegning herom.

For hver enkelt kommune samordnedes derefter skemaerne fra grupperne A og B i en alfabetisk række, der nummereredes fortløbende, gennemhulledes og sammenhæftedes til sognets nationale register over optagne. Der blev gjort udtrykkelig opmærksom på, at de endelig ikke måtte syes sammen, således som det hidtil havde været skik efter tysk forvaltningsskik. På tilsvarende måde behandledes gruppe $\mathrm{C}$ skemaerne, der udgør det nationale registers afdeling for ikke optagne. Senest 15 . december afholdtes et nyt kommunalbestyrelsesmøde, hvor registrene godkendtes og samlet blev underskrevet af samtlige tilstedeværende kommunalbestyrelsesmedlemmer. Næste trin var listernes offentlige fremlægning. 
Listerne fremlagges til gennemsyn

Som allerede nævnt ovenfor var der tale om en meget stram tidsplan, og det blev da også nødvendigt allerede i oktober at lave om på tidsfristerne, således at listernes fremlægning til offentligt gennemsyn på kommunekontorerne først fandt sted fra 1.-15.jan. 1922, i stedet for som planlagt 15.-30. december 1921, som vel også må siges at være et noget upraktisk tidspunkt. På grund af byens størrelse fik Aabenraa yderligere udsættelse, således at fremlægningen der først fandt sted 15. til 30. jan. 1922.

Lillejuleaften 1921 indskærpede amtet - som det hedder i embedsmandssproget »På dertil given foranledning undlader man herved ikke at henlede kommunalbestyrelsernes opmærksomhed på« at fremlæggelsesfristen nøje måtte overholdes, og den 30 .december fremsendtes en fælles bekendtgørelse

\section{De Dationale Registre.}

Cfitex at bex af Rommuneme ex optaget Megifite ( $n$ Rae

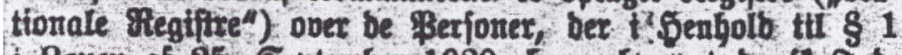
it Qoven of 25. September 1920 bar erfjoerbet banft Snb. (bosret, ftal man berbeb brtnge til alminbeltig Sumbitab,

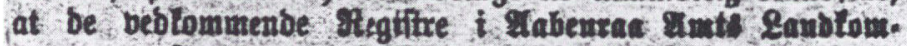

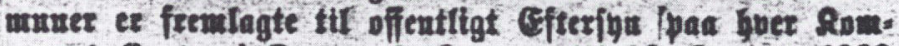
mure Runtor 1 Dageut 1 . Saunat ti 18 Saunat 1922 infl. Iñen 28. Januar 192.2 tan enhber $\$$ exjon over 18 Lat fremfore Silage ober be Rationale $\Re$ giftre ellex en ub. ftebt \&ifteits Figtigheb. Slagen tan gas us paa, at en Berfou meb Urette ex optoget ellex ttle optaget $t$ Fegiftret. Rlagen inbgives ftriftitg til be Rommunalbefintelie, bex

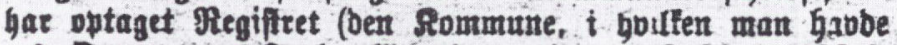
laft Dpholo paa folfetallingsoagen ben 1. Ffebruar 1921), og Slagen vil blive afgiort af imtet.

Dpmartfombebes Genlebes paa ben Betybnintg, ber foil Gave for engoer at faa fiute ftatsborgerlige Siettig geber lon. ftateret, ibet Inbfobsretten ex en Betungelfe. for be bigtigfte borgerlige og poltiffe $\Re$ ttigheber.

Om Jremlaggelíe of Regutrene $i$ Fabenta Rabitab bif fenere fremtomme Betenotgorelfe.

Vabenrad Int, bent 30. Dec, 1921.

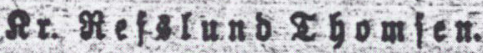

Gennem annoncer $i$ de sonderjyske dagblade blev det ved drsskiftet 1921/22 meddelt, at registre over personer tildelt dansk indfodsret var fremlagt til offentligt eftersyn. Evt. klager skulle indgives senest 23. januar. Annoncen her er gengivet efter Apenrader Tageblatt 3. januar 1922. 
fra amtet til de fire aviser Hejmdal, Flensborg Avis, Apenrader Tageblatt og Aabenraa Amts Socialdemokrat. Af annoncen fremgår det, at registrene var fremlagt på kommunekontorerne, og at enhver person over 18 år kunne fremføre sin klage over fejl og urigtigheder ved attesterne (idet også bilagene fremlagdes til offentlig indsigt), over optagelse eller over manglende optagelse i de nationale registre. Klager skulle indgives inden 23. januar 1922 til kommunen og ville blive behandlet af amtet. Sluttelig henvistes der til vigtigheden af at få sine statsborgerlige rettigheder konstateret, videt Indfødsretten er en Betingelse for de vigtigste borgerlige og politiske Rettigheder.« For Aabenraa by fastsattes klagefristen til 8. februar. Da magistraten i Aabenraa d. 13. marts indsendte nationalregisteret for kommunen, kunne man konstatere, at registeret over de optagne personer indeholdt 2806 blade, medens 1096 var henlagt i mappe C som ikke optagne.

Med fremlæggelsen og modtagelsen af eventuelle klager var kommunernes arbejde i det væsentligste overstået. Iøvrigt indkom der meget få klager, fra Løjt sogn således overhovedet ingen, og det var nærmere reglen end undtagelsen. Efter klagefristens udløb indsendte kommunalbestyrelsen hele materialet til politimesteren, hvis pligt det kun var at undersøge klagerne og ikke andet. Behandlingen af klagerne skete på den måde, at der blev optaget et politiforhør, som derefter blev vedlagt, når sagerne videreekspederedes til amtet. At ikke alle kommuner havde forstået, at de ikke kunne blive ved med at meddele optagelse i det nationale register fremgår af, at amtsassessor Bang i maj 1922 så sig nødsaget til at udsende et cirkulære herom til samtlige sognerådsformænd i Aabenraa amt, hvori det præciseredes, at alle afgørelser skulle træffes af amtet. Det var imidlertid ikke kun klager om nye ansøgninger, der skulle behandles. I en skrivelse fra Indenrigsministeriet af 25. marts 1922 havde departementschef F.C. Martensen-Larsen understreget, at da det var amtet, der $i$ henhold til cirkulæret af 25 . april 1921 om nationale registre traf den endelige afgørelse om alle indførsler i registrene, måtte samtlige registerblade med bilag gennemgåes på amtets kontor, uanset om der var rejst klage eller ej. Et større arbejde forestod således amtets embedsmænd.

\section{Amterne efterkontrollerer}

Ved den afsluttende gennemgang på amtet blev alle skemaer over optagne personer, som amtet kunne godtage, forsynet med stemplet »Optaget. Aabenraa Amt $«$, men i en rakke tilfælde underkendte amtet den afgørelse, som kommunen havde truffet. Dette synes især at være tilfældet i de mindre landkommuner. Disse fik så stemplet »Optages ikke. Aabenraa Amt«. Desuden tilføjede amtet enkelte nye skemaer uden for nummerfølgen i begge rækker. Der viste sig at være en lang række tilfælde, hvor der var tvivl om, hvorvidt afgørelsen 
var truffet på et fyldestgørende grundlag. Det var derfor nu op til amterne at efterkontrollere, dels ved at udsende breve til pågaldende om at skaffe de manglende bevisligheder, dels ved at lade optage forhør gennem de stedlige politimyndigheder. Til dette brug udarbejdedes der ved de enkelte amter særlige skemaer, som sammen med attesterne indgik som en væsentlig del af de pakkesager, der er tilknyttet det nationale register, og som vil blive nærmere omtalt nedenfor.

Behandlingen af optagelserne kunne imidlertid trække længe ud, og ved adskillige af skemaerne for de allerede optagne findes amtets stempel med oplysning for dato for endelig optagelse langt frem i 1930erne. Også for de ikke optagne var der naturligvis mulighed for, at sagsbehandlingen kunne fortsatte, men en behandling af dette spørgsmål vil, ligesom en behandling af hele spørgsmålet om tildeling af dansk indfødsret, som tidligere næunt føre for vidt i denne sammenhæng. For omkring $50 \%$ af de ikke optagne gjaldt det ganske simple forhold, at de var født i Danmark og danske statsborgere, og at de derfor ikke opfyldte den første betingelse for optagelse, nemlig at de indtil 15. juni 1920 skulle være i besiddelse af tysk statsborgerskab. De øvrige, som ikke blev optaget (de tyske statsborgere) faldt på, at de ikke opfyldte kravet om ophold i landsdelene uafbrudt fra 1.oktober 1918 til 15.juni 1920, eller, for et forbløffende stort antals vedkommende på, at de ikke dokumenterede deres ophold, idet de simpelthen undlod at reagere på kommunens og senere amtets henvendelse desangående inden for den fastsatte frist.

\section{Det nationale registers aflevering til Landsarkivet}

Da de gamle amter efter forvaltningsreformen i 1970 skulle afvikles, blev der truffet aftale om aflevering af deres arkivalier til Landsarkivet, når de kunne undværes i administrationen. Selve de kommunevis opdelte registre afleveredes derfor ikke, netop ud fra den begrundelse, at de stadig hyppigt anvendtes og ikke kunne undværes $i$ det daglige arbejde. Der var dels tale om udstedelse af udskrifter og attester fra registeret dels om brug af oplysninger i forbindelse med indfødsretssager og andre personsager. Ved tildeling af dansk indfødsret blev meddelelse herom med henvisning til amtets journalnummer stadig indført i registrene. Registrene fra alle de tidligere sønderjyske amter blev derfor samlet i Aabenraa på Statsamtet. Det samme gjaldt indfødsretsjournalerne fra Tønder amt. Derimod afleverede Tønder amt ved afviklingen i 1973 som en samlet gruppe 138 pakker journalsager vedr. indfødsret frem til 1952 samt bilagene til det nationale register ordnet sognevis, ialt 52 pakker samt 2 pakker, der var brugt ved forarbejderne, jvf. nedenfor. For det gamle Haderslev stiftamts vedkommende afleveredes i december 1978 ligeledes en samlet gruppe bestående af optantsager nr. 1-729, indfødsretsbeviser nr. 4-12505 samt 32 pak- 
ker bilag til nationalregisteret ordnet sognevis. For de gamle Aabenraa og Sønderborg amter afleveredes indfødsretssagerne sammen med de øvrige amtsarkivalier, medens både de originale registre og bilagene til nationalregisteret blev holdt tilbage.

I 1992 indledte Landsarkivet nye forhandlinger med stiftamtmand Ole Perch-Nielsen og amtskontorchef Knud Jessen, som tilkendegav, at det nationale register nu anvendtes så sjældent, at tiden var moden til en overførsel til Landsarkivet. Efter en gennemgang og soignering af materialet afleveredes det originale nationale register fra de 4 gamle amter med tilhørende registre samt bilagsmaterialet fra Aabenraa og Sønderborg amter derefter i december 1992 til Landsarkivet, hvor denne nye aflevering er opstillet samlet under betegnelsen »Det nationale register 1921 «. Hele materialet er inden afleveringen fortløbende nummereret fra nr. 1-470. Disse numre kan anvendes ved rekvisition til brug på Landsarkivets læsesal. Derimod skal bilagene fra Tønder og Haderslev amter fortsat søges i disses arkiver på Landsarkivet.

\section{Materialet}

Grundstammen i nationalregisteret udgeres af de sognekommunevis indbundne skemaer over henholdsvis optagne og ikke optagne personer, ialt 378 bind i folioformat. Bindene fordeler sig på følgende måde på amterne: Aabenraa amt 80 bind, Haderslev amt 132 bind, Sønderborg amt 72 bind og Tønder amt 94 bind. Når antallet af bind fra Sønderborg amt er uforholdsmæssigt lille, skyldes det, at skemaerne over ikke optagne for dette amt normalt ikke er indbundet og følgelig skal findes i de tilhørende pakkesager, jvf. nedenfor. Skemaerne er ordnet strengt alfabetisk efter husstandsoverhovedets efternavn inden for hver sognekommune og forsynet med et fortløbende nummer+et skemanummer fra statistisk departement. Sidstnavnte nummer kan ikke anvendes til noget. Som tidligere anført rummer skemaerne oplysninger om navn, bopæl, fødselsdag, stilling i familien, erhverv samt bopæl fra 1.okt. 1918 til 15. juni 1920 og statsborgerlig stilling 15. juni 1920. Dertil kommer antegnelser om optagelse m.v., evt. med henvisning til amtets journalnummer. Et skema omfatter en familie (husstand) og rummer tilsvarende personlige oplysninger om hustru og børn under 18 år. Fødested er almindeligvis ikke anført, men i nogle kommuner tilføjet. Til dette grundmateriale slutter sig pakkerne indeholdende de tilhørende bilag fra sagsbehandlingen ved amtet.

Selvom der kan være forskelle fra amt til amt i henlæggelsen af bilagene, er materialet i hovedtræk ens. Sagerne er for hver enkelt sognekommune ordnet efter de to grupper, som kommunerne havde henlagt de oprindelige skemaer i, "Optagne" og "Ikke-optagne«, og herunder på skemanummer, dvs. alfabetisk. Man skal være opmærksom på, at der kun kan findes materiale om de 
sager, hvor der er foregået en egentlig sagsbehandling ved amtet. Alligevel er antallet af pakker ganske stort. Fra Aabenraa amt 13 pakker, fra Haderslev amt 22 pakker (i amtsarkivet), fra Sønderborg amt 44 pakker og for Tønder amt 52 pakker (i amtsarkivet). For Sønderborg amt gør der sig, som tidligere nævnt, det forhold gældende, at skemaerne over de ikke-optagne ikke blev indbundet med undtagelse af et par sogne men henlagt som pakkesager.

I Tønder amt var grev O. D. Schack blevet udnævnt til amtmand, og da han var uden erfaring som administrativ embedsmand, fik han allerede i febr. 1920 en af Indenrigsministeriets dygtige fuldmægtige, P. Chr. von Stemann, udstationeret som designeret amtsassessor. Det er tydeligt, at det er en erfaren embedsmand, der har styret sagsbehandlingen ved amtets gennemgang af sagerne til nationalregisteret, og den er klart præget af dansk administrativ tradition, hvilket ikke gælder for alle de øvrige amters sagsbehandling.

Bilagsmaterialet fra Tønder amt er derfor særdeles velordnet og kan tjene som eksempel på, hvorledes en sognepakke kan tage sig ud. Den begynder med en liste over udstedte bopælsattester, hvorefter selve attesterne følger. Resten af pakken udgøres af to omslag indeholdende de sager for henholdsvis optagne (betegnet I) og ikke-optagne (II), som er blevet behandlet af amtet. Til hver gruppe er der vedlagt et alfabetisk register over personerne. Hver enkelt sag er indlagt $i$ et sagsomslag, hvor amtet har noteret pågældendes nummer i nationalregisteret, og hvor en del af sagsbehandlingen kan følges, f.eks. typisk fremsendelsen til politimesteren. I omslaget ligger selve akterne som f. eks. kan være det udfyldte afhøringsskema, en optaget rapport eller de ønskede attester og et notat om sagens afgørelse, som i de positive tilfælde lyder: "Det meddeles Dem herved tjenstligt, at De i følge Amtets Resolution nu er blevet optaget i det Nationale Register for NN Kommune."

Med gennemgangen af de indbundne skemaer og det tilhørende bilagsmateriale er omtalen af selve det nationale register i og for sig afsluttet. Imidlertid har amterne i forbindelse med dets udarbejdelse sammenkoblet det med andet materiale vedr. udfærdigelse af indfødsretsbeviser samt afgivelse af optionserklæringer. Dette materiale er hovedsageligt afleveret sammen med det nationale register og af såvel amterne som Indenrigsministeriet betegnet som hørende til dette. Det bør derfor kort præsenteres.

\section{Det supplerende materiale}

Væsentligst er de to registerrækker: Alfabetiske navneregistre og kronologiske registre. De alfabetiske navneregistre angiver navn, livsstilling og bopæl samt henvisning til det kronologiske register med protokolsignatur, folio og nummer, men ikke henvisning til nummeret i det nationale register. Det kronologiske register, som går tilbage til tiden umiddelbart efter genforeningsdagen, 
indeholder en række vigtige personalhistoriske oplysninger, som kan supplere oplysningerne på skemaerne i det nationale register. Det er anlagt som register over udstedte indfødsretsbeviser og fortsatte også som sådan efter afslutningen af det nationale register. Det kronologiske register indeholder følgende rubrikker: Fulde navn (med bemærkning: i registeret indføres også sådanne personer, som omfattes af vedkommende hovedpersons erhvervelse af indfødsret), fødselsdag og år, fødested, livsstilling, bopæl 15.juni 1920, bopæl ved attests udstedelse, dato for udfærdigelse af attesten, amtets journal $\mathrm{nr}$. og bemærkninger (Ministeriets afgørelse). Sidstnæunte kan f.eks. være: "Attest udfærdiget af Indenrigsministeriet 29. sept. 1920 og udleveret den pågældende personligt«. Som det sees, er der ikke direkte henvisninger fra disse registre til det nationale register, men da en del personer vil forekomme begge steder, kan oplysningerne supplere hinanden samtidig med, at der i registrene kan findes oplysninger om personer, som af den ene eller anden grund ikke kom med i det nationale register. Det samme galder de tilsvarende registre over optanter, der ligeledes er afleveret $\mathrm{i}$ tilknytning til det nationale register fra de 4 amter. Disse registre giver desuden dato for optionserklæringens afgivelse og for amtets udfærdigelse af kvittering, journalnummer og nummerhenvisning til ministeriets optantregister.

Afslutningsvis, og som illustration af den grundighed man ved Tønder amt lagde for dagen ved behandlingen af oprettelsen af det nationale register, skal navnes to pakker afleveret fra Tønder amt under betegnelsen: Indfødsret (National register): 7 april $1898 \mathrm{~m} . \mathrm{m}$. Gamle tyske lister fra forskellige sogne. Under denne noget kryptiske titel skjuler sig en række lister udarbejdet af de daværende amtsforstandere til amtsretterne vedrørende følgende 5 persongrupper:

1. Personer af dansk afstamning, som er født her i landet (hier im Inlande) og disses børn.

2. Personer af dansk afstamning, som er født i Danmark og før 7.april 1898 er tilvandret (hierher ins Inland zugewandert) samt deres børn.

3. Optanter.

4. Optantbørn a. født før 1.april 1898

b. født efter 1.april 1898

5. Personer af dansk afstamning, som er født her (hier im Inlande) og deres børn.

Til disse lister, der har været nyttige i forbindelse med udvisningspolitiken i Køller-tiden, slutter der sig i en række tilfælde lister over til- og afgang til dem. Endelig findes der i pakkerne fuldstændige optantlister fra Rømø, Ballum, Brede, Døstrup, Visby og Møgeltønder samt en liste over de i Tønder bosatte danskere. Det 
kan næsten betegnes som et af historiens luner, at samme lister senere blev anvendt af de danske myndigheder på en positiv måde for de samme personer.

\section{Tilgangelighed og anvendelse}

Allerede medens det nationale register befandt sig på Sønderjyllands Statsamt, var dets eksistens bekendt for historikere, som benyttede sig af muligheden for at anmode om oplysninger fra det omfattende personalhistoriske materiale. $\mathrm{Da}$ en af disse henvendelser gav anledning til principielle overvejelser om tilgængelighedsspergsmålet, skal den her omtales.

Det drejer sig om folkemindeforskeren og cirkushistorikeren Anders Enevig, for hvem det var vigtigt at kunne spore nogle af de omvandrende artister, som ellers kan være meget vanskelige at følge. Han rettede derfor i 1979 en henvendelse om adgang til visse oplysninger gennem amtet, der videresendte den til Indenrigsministeriet. Her overvejedes sagen grundigt, og efter forst at have fastslået, at der var tale om oplysninger hørende til privatlivet, endte man alligevel med at frigive oplysningerne med følgende begrundelse:

"Af Indenrigsministeriets cirkulære nr. 109 af 25. april 1921 fremgår det imidlertid, at oprettelsen af de deri omhandlede nationale registre har fundet sted, efter at de har været fremlagt til offentligt eftersyn, ligesom der i cirkulæret findes en bestemmelse om, at enhver offentlig dansk myndighed og enhver person over 18 år kan kræve at få udfærdiget en udskrift af et sådant register. Under hensyn hertil er indenrigsministeriet af den opfattelse, at enhver person - ikke blot den, som oplysningen vedrører - kan forlange at få oplysninger fra disse registre vedrørende bestemte navngivne personer. Under hensyn til den nære sammenhæng mellem de nationale registre og de af de sønderjyske amter førte registre over de af amterne udfærdigede midlertidige indfødsretsbeviser samt optantregistrene, vil Indenrigsministeriet endvidere antage, at det samme må gælde for de to sidstnævnte registres vedkommende«.

Efter registrenes aflevering til Landsarkivet rejste dette tilgængelighedsspørgsmålet overfor rigsarkivaren med indstilling om fri tilgængelighed under henvisning til Indenrigsministeriets afgørelse fra 1979, hvilket rigsarkivaren har tilsluttet sig. Materialet er derfor nu frit tilgængeligt på Landsarkivet for fremtidig forskning. Man skal dog være opmærksom på, at indfødsretssager, der ikke direkte er koblet sammen med det nationale register, stadig falder ind under arkivlovens bestemmelser om beskyttelse af personlige oplysninger i 80 år efter sagens afslutning. Dispensation kan dog gives til forskningsbrug.

En række undersøgelser af slægts- og personalhistorisk karakter vil kunne gennemføres på grundlag af registrenes oplysninger, som på visse punkter fylder hullet mellem de manglende folketællinger fra den prøjsiske administrations tid og den endnu ikke almindeligt tilgængelige danske folketælling 1921 
samt mellem de ufuldstændige melderegistre og de danske folkeregistre, der begynder i 1924. Man skal dog ikke forestille sig, at de nationale registre giver et fuldstændigt billede af befolkningen på genforeningsdagen, da grundlaget jo som ovenfor anført er folketællingen 1921. Det kan iøvrigt undre, at der ikke på noget tidspunkt under registrenes udarbejdelse er forsøgt en kobling til listerne over stemmeberettigede ved folkeafstemningen 10. febr. 1920, men dette sees ikke at være tilfældet.

Undersøgelser over optantspørgsmålene vil kunne have stor nytte af materialet omkring de nationale registre, og det skal her tilføjes, at den ene af de to ovennævnte pakker fra Tønder amt med diverse lister også rummer fortegnelser udfærdiget af Udenrigsministeriet over personer, der har opteret for Tyskland $\mathrm{i}$ henhold til den dansk-tyske overenskomst om statsborgerskabstilhørsforhold af 24. juli 1922.

Selve spørgsmålet om tildeling af dansk indfødsret til personer, som ikke fik spørgsmålet afklaret i 1921, kunne også indbyde til en undersøgelse bl.a. af hvilke social- og aldersgrupper, der har søgt dansk indfødsret på hvilket tidspunkt. Ved blot et hurtigt blik i de kronologiske protokoller bliver det meget tydeligt, at der kan tegnes en interessant kurve bl.a. over udviklingen i 1930erne. Den viser en påfaldende stejl stigning, da faren for en anden verdenskrig med deraf følgende tysk militærtjeneste begynder at gå op for dem, der kunne blive indkaldt, men det er selvfølgelig kun et aspekt i det omfattende materiale.

Formålet med artiklen har ikke været at udarbejde et forskningskatalog, men kun at give en første redegørelse for dette spændende materiale, der nu er tilgængeligt for forskningen, og gøre opmærksom på dets eksistens. Jeg håber, at artiklen opfylder dette formål, men er mig vel bevidst, at heller ikke skildringen af registrenes tilblivelse er udtømmende. Også her venter en opgave, som på et stort materiale kunne afdække interessante sider af administrationen i de sønderjyske landsdele i overgangstiden efter genforeningen. For yderligere at tilskynde til brugen af det nationale register vil Landsarkivet udsende en trykt registratur over materialet forsynet med en kort indledning og vejledning i materialets benyttelse, formentlig i slutningen af 1994.

\section{NOTER}

Jeg vil gerne takke cand.mag. Kim Furdal, fordi han under sit arbejde som forskningsrådsstipendiat med en opgave om indforelsen af den danske kommunale forvaltning i Nordslesvig. "Genforening i praksis", har ladet mig gennemse manuskriptet, hvorfra flere enkeltheder, dog ikke om selve nationalregisteret, er hentet. Kim Furdals afhandling forventes at blive offentliggiort i 1995.

Lovstoffet:

Lovtidende 1920. Sagregisterstikord Senderjylland 
Lov nr. 474 af 5te sept. 1920 om erhvervelse af dansk indfødsret $i$ anledning af de sønderjyske landsdeles indlemmelse i Danmark

Lovens forelæggelse: se Rigsdagstidende for Rigsdagens overordentlige samling 1920 Folketingstidende sp. 477

Lovbekendtgørelse nr. 293 af 12.juni $1922=$ den ændrede indfødsretslov

Versaillestraktatens artikel 112 og 113

Franz v. Jessen: Haandbog i det slesvigske Spørgsmaals Historie bd. III, 1920-37, s. 19-20

\section{Indenrigsministeriets cirkularer:}

Ministerialtidende A 1920: nr. 259 af 22. sept. 1920: Cirkulære til Københavns Magistrat og samtlige Amtmand (om erhvervelse af dansk indfødsret $i$ anledning af de sønderjyske landsdeles indlemmelse i Danmark)

Ministerialtidende A 1921: nr. 109 af 25. april 1921: Cirkulære til amtmændene over Haderslev, Aabenraa, Sønderborg og Tonder amter (om nationalregistrene)

Ministerialtidende A 1921: nr. 134 af 31.marts 1921 (om "fast bopæl«)

De interne cirkulærer om nationalregistrenes udfardigelse findes i Det nationale register pk. 99 Aabenraa amt. Diverse akter samt bopalsattester og optanter for Tyskland (LA.)

Iøvrigt henvises der ikke til de enkelte benyttede bind og pakker fra det nationale register.

Aflevering og tilgangelighed:

Landsarkivets afleveringsjournaler $A 1$ og 4, samt afleverings journalsag A 1-21-93.

Landsarkivets skrivelse af 16 . febr. 1994 til Rigsarkivar Johan Peter Noack og dennes svar af 18. marts 1994, RA. j. nr 610-59.

P. Chr. v. Stemann, der senere blev amtmand på Bornholm, har i sine erindringer: En dansk embedsmands Odysse, bd. I (1961) s. $37-77$ skildret tiden på amtet i Tonder, ligesom O. D. Schack har det i sine erindringer "Grænsesind « (1970), men ingen af dem kommer ind på arbejdet med det nationale register.

Listerne i Tonder amtsarkiv om danske statshorgere m.v.:

Disse listers optagelse må antagelig sees i forbindelse med udstedelsen af den nye danske indfødsretslov: Lov nr. 42 af 19. marts 1898 om Erhvervelse og Fortabelse af Indfødsret, selvom dennes sidste stykke udtrykkeligt anfører, at den ikke galder for de personer, der efter fredstraktaten af $\mathbf{3 0 . ~ o k t . ~}$ 1864 artikel XIX er forbeholdt indfødsret. 